\title{
Pathologic Stage IV Cutaneous Melanoma AJCC v8
}

National Cancer Institute

\section{Source}

National Cancer Institute. Pathologic Stage IV Cutaneous Melanoma A/CC v8. NCI

Thesaurus. Code C137677.

Stage IV includes: Any T, T is, Any N, M1. T is: Melanoma in situ. Thickness: Not applicable. Ulceration status: Not applicable. M1: Evidence of distant metastasis. (AJCC 8th ed.) 